УДК 398(477) (092)

DOI:

Дзвенислава Василик, стариий викладач кафедри методики музичного виховання і диригування Інституту музичного мистеитва Дрогобищького державного педагогічного університету імені Івана Франка

\title{
ФОЛЬКЛОРИСТИЧНА ДІЯЛЬНІСТЬ АНТІНА КНЯЖИНСЬКОГО
}

У статті подано коротку історію життя $і$ творчості західноукрайнського педагога, науковия, письменника, етнопсихолога, мовознавия, фольклориста Антіна Петровича Княжинського. Професор Антін Княжсинський є людиною, щчо викликає величезний інтерес, велику працездатність і непереможсн силу духу. Зроблений короткий аналіз фольклористичних та літературознавчих прачь професора Княжинського. Висвітлено значення його наукової та фольклористичної діяльності.

Ключові слова: Антін Княжсинський; “Бойківщина”; фольклор; етнопсихологія; національна культура. Jim. 15.

Dzvenyslava Vasylyk, Senior Lecturer of the Methodology of Music Education and Conducting Department Institute of Musical Art Drohobych Ivan Franko State Pedagogical University

\section{FOLKLORE ACTIVITY OF ANTIN KNYAZHYNSKIY}

The beginning of the twentieth century for the culture of Galicia was particularly rich: in contrast to political and economic problems, Ukrainian education, musicology, folklore, linguistics, and literature were developing. Already from the 90 s of the twentieth century, Ukrainians were able to legally process materials from the pre-Soviet period, publish information about the leaders of Ukrainian culture and science banned by the Soviet authorities, and study their creative achievements. To the little-known, unfortunately, names in the fields of pedagogy, sociology, ethnopsychology and folklore belongs the name of Dr. Antin Knyazhynskiy, one of the accomplices of the development of Ukrainian education, science and culture in Galicia 20-30 years of the last century.

Professor Antin Knyazhynskiy is a man of great interest, great work ability and invincible strength of spirit. Having put his life on the altar of service to his native people, he tried to direct all his forces to the development of Ukrainian education, culture and science: the teacher - was a teacher of the Ukrainian language and literature in the gymnasiums of Yavoryv, Drohobych, Ternopil, Sambir, Kolomyia and the seminary in Sambir; co-founder of the Society and the Boykivshchyna Museum in Sambir; author of scientific works on ethnopsychology, sociology, folklore, literary studies; editor, actor, director, ethnographer, writer. In 1945-55 he was a prisoner of concentration camps of the USSR.

The article gives a brief history of the life and work of Antin Knyazhynskiy. A brief analysis of the folklore and literary works of Professor Knyazhynskiy is made. The significance of his scientific and folklore activity is highlighted.

Keywords: Antin Knyazhynskiy; "Boykivshchyna"; folklore; ethnopsychology; national culture.

П остановка проблеми та аналіз основних досліджень та публікацій. Початок XX ст. для культури Галичини був особливо насиченим: в протистоянні політичним та економічним проблемам розвивалися українські освіта, музикознавство, фольклористика, література. Велика частка матеріалів за часів радянської влади були знищені, або ж засекречені. Аж 3 90-х років XX ст. українці дістали можливість легально опрацьовувати матеріали дорадянського періоду та публікувати інформацію про колись заборонених діячів української культури та їхні творчі здобутки. До маловідомих імен в царині педагогіки, соціології, етнопсихології та фольклористики належить ім'я доктора Антіна Княжинського, одного із сподвижників розвитку української освіти і культури в Галичині 20 - 30-х рр. XX ст. Наукових досліджень про Антона
Княжинського на даний час немає. Окремі статті та згадки про його творчість і життя опублікували Б. Стебельський, К. Куб'як, Я. РадевичВинницький, М. Лесів. М. Андрусяк.

Перша стаття про Антіна Княжинського в Україні була написана і опублікована Костем Куб'яком у самбірській газеті "Самбірські вісті" у 1992 році “Хто ж він - Антін Княжинський?”, у якій автор висвітлив життєвий шлях професора Самбірської гімназії доктора Княжинського. У 100-ліття $з$ дня народження А. Княжинського цей же дослідник його життя і творчості опублікував статтю "Перщий почесний громадянин Самбора", у якій вперше появилася публікація тексту почесної грамоти, якою А. Княжинський був нагороджений у 1938 році: “Зорганізоване громадянство вільного города Самбора признає отсею грамотою високоповажаному професорові 
Антонові Княжинському за його довголітню жертвенну виховну і науково-суспільну працю для величі української нації ім'я першого почесного громадянина українського суспільства города Самбора" [12].

Про фольклористичну та педагогічну діяльність професора Антіна Княжинського наукових статей немає, оскільки для широкої аудиторії його ім'я невідоме.

Познайомити наукову громаду 3 постатю Антіна Княжинського, висвітлити фольклористичну діяльність Антона Княжинського - мета статті.

Виклад основного матеріалу. Професор Антін Княжинський - людина обширних зацікавлень, великої працездатності та незламної сили духу. Поклавши своє життя на вівтар служіння рідному народові, намагався всі свої сили спрямовувати на розвиток української освіти, культури і науки: педагог - був викладачем української мови і літератури у гімназях Яворова, Дрогобича, Тернополя, Самбора, Коломиї та вчительської семінарії у Самборі; співзасновник товариства і музею "Бойківщина" в Самборі у 1927 році (разом з В. Гуркевичем, В. Кобільником, М. Скориком, І. Филипчаком, В. Кордубою та ін.), у 1937 - 38 рр. - голова товариства; автор наукових праць 3 етнопсихології, соціології, фольклористики, літературознавства; редактор, актор, режисер, етнограф, письменник. У 1945 55 рр. - в'язень концентраційних таборів СРСР.

Народився Антін Княжинський уселі Тисовиця 20 лютого 1893 року в родині священика УГКЦ Петра Княжинського. В родині було троє дітей Антін, Юрій і Свгенія. Початкову освіту отримав Антін Княжинський у Самборі: спочатку закінчив чотирьохкласну школу, а потім Першу державну класичну гімназію. Поступив у Львівський університет на юридичний факультет. Там здобув ступінь доктора філософії і став учителювати. Першим місцем праці була приватна українська гімназія в Яворові. У 1920 році переїхав до Самбора, де викладав українську мову у своїй “альма матер" - гімназії, що колись закінчив, а 3 1921 року і в жіночій учительській семінарії, яка була відкрита в цей рік. У 1938 році переїжджає у Коломию, де працює спочатку викладачем, а потім - директором гімназії, а 31941 року призначений головою Окружного комітету української влади. У 1943 році з наказу УЦК переїздить у Новий Санч, де очолює Окружний комітет. 1944 рокупереноситься до Відня, мешкає у містечку Кльостернайбург, яке з 1938 по 1954 р. входило до складу Відня.

У 1945 році на Великдень (6 травня) був заарештований НКВД. У 1945 - 55 pp. - в’язень концентраційних таборів СРСР. У 1955 році А. Княжинського було звільнено. Статус підданого Австрії дав йому змогу повернутися до Відня, а звідти він вихав у Філадельфію, США. Спогади про перебування в таборах "На дні СССР” були опубліковані А. Княжинським у 1959 році у США.

Будучи в емігації, відновив з пам'яті втрачену книгу “Дух нації: соціологічно-етнопсихологічна студія”, яка вийшла друком у 1959 році. Праця була готова до друку на початку березня 1938 р. і публікація іï планувалася НТШ на 1939 рік. Але почалася більшовицька окупація i, побоюючись ревізії, професор Княжинський заховав матеріали, що повернув йому тодішній голова НТШ професор Іван Раковський: “...замурував я те все в селянській печі близької місцевости. Там і зотліли всі матеріяли й кінцева частина першої праці, де виклав я свій погляд на методу досліду" $[5,4]$. Перебував тоді професор Княжинський у Коломиї, де був професором гімнаії.

3 позицій соціології та психології аналізує професор Княжинський життя і творчість Лесі Українки у праці “Творчий шлях Лесі Українки”. Книга була видана у Філадеьфії в 1961 році Союзом Українок Америки з нагоди відкриття пам'ятника Лесі Українки в Клівленді і на закінчення 90-х роковин їі народження. Перша публікація цієї книги вийшла друком у Кракові в 1941 році під назвою “За духа нації: Леся Українка: життя і творчість” під псевдонімом Н. Антоненко. Аналізуючи зміст духовності та світогляду українців періоду 80 х рр. ХІХ ст. - 10-х рр. ХХ ст., вважає, що “...Леся Українка, найідеальніший витвір духа української нації, що нехтувала собою, посвячуючи свою особу найвищій життьові правді - духові нації” [7, 13 - 14]. Творчість Лесі Українки А. Княжинський подає у своїй праці через призму національної ідеї і вважає, що вона “знайшла шлях апостола духа” [7, 14]. Аналізуючи “Триптих” Лесі Українки, А. Княжинський доходить висновку: “Так геніально розв'язала Леся ряд поставлених питань. Три складові елемети їх одиницю-народнацію увела в рамки триптиха, зазначаючи цим робом нерозривність цих елементів..." [7, 54].

У збірнику Записок НТШ “Тарас Шевченко”, 3 нагоди вшанування патрона НТШ була опублікована аналітична стаття Антіна Княжинського. У статті “Філософія Шевченка" Антін Княжинський критично аналізує праці “підсовєцьких “шевченкознавців” [8], які вважали Шевченка матеріалістом. Аналізуючи світогляд поета на основі його творчості, висновує, що Тарас Шевченко “був представником і творцем окремої філософічної системи” [8, 37]. Професор Антін 
Княжинський вважає Шевченка “творцем українського ідеалізму" [8, 39].

Найбільшим періодом педагогічної, наукової і фольклористичної діяльності професора Княжинського є час його перебування на посаді професора державної гімназії у Самборі - 1920 $1938 \mathrm{pp}$.

У гімназії та жіночій вчительській семінарії “Рідної школи" Самбора, що була заснована Теодором Біленьким у 1921 році, А. Княжинський викладав українську мову. Колишня учениця семінарії Ярослава Турчан на вечорі пам’яті Антіна Княжинського, що відбувся у 1993 році, згадувала: “Його уроки - це була поезія у прозі. Вони були приймані ученицями з великою увагою і глибокою пошаною. Форма і зміст уроку були завжди добре продумані. На його уроках ми почули і про Хвильового, і про Кримського, про Чупринку i про Олександра Олеся, про Рильського, про Грушевського, про Єфремова, про Тичину, про Шевченка і Франка, і Лепкого. Але як чудово він пояснював твори Лесі Українки".

В часі своєї педагогічної діяльності доктор Княжинський публікував статті на педагогічні теми в тогочасних українських часописах "Учительське слово", "Українська школа" та ін.

Від початку створення товариства і музею “Бойківщина" доктор Княжинський був активним учасником товариства і публікував свої наукові статті в “Літописі Бойківщини”, видання якого почалося у 1931 році.

Михайло Скорик у 1937 році у статті “В десятиліття існування Товариства та Музею "Бойківщина" в Самборі" так характеризує діяльність Антіна Княжинського: “Др. Антін Княжинський зацікавлений у різних проявах життя бойківського племени, працював на полі досліду бойківського говору; означує границі Бойківщини (його означення на півдні Бойківщини приймає дослідник цих говорів Др. І. Панькевич). Нотував причинки до звичаєвого права бойків. Навязав перший контакт музею з Турчанщиною, частинно зі Стриєм. Помагав у складанні бібліографії Бойківщини. Був першим світливцем музею. Через кілька літ, від 1932 р. до кінця десятиліття був секретарем музею" $[15,13]$.

Уже в першому числі “Літопису” були опубліковані три праці Антіна Княжинського: "Межі Бойківщини”, “Як записувати твори “усної словесности”, "Причинки до звичаєвого права на Бойківщині. Свідоцтво землі. Кара за крадіж на полі”.

Розвідка “Межі Бойківщини” була підготована до друку в грудні 1930 р. На основі власних етнографічних та фольклористичних досліджень, порівняльного аналізу бойківських, лемківських, гуцульських говірок, спираючись на праці таких дослідників як I. Верхратський, І. Свєнціцький, В. Гнатюк, І. Панькевич, викладає своє розуміння Бойківщини: "Бойківщина не лише діялектично ріжна від сусідів, бо бойки се в повному розумінні сього слова окреме племя, яке виказує свій питомий тип, яке має питомі собі признаки побуту, як будівництво, одяг, звичаї тощо” [4, 24]. Професор Княжинський пропонує "прийняти поділ бойківського діалекту на три групи: 1) підгірський, що обіймає північне (галицьке) Підкарпаття, 2) верховинський, що обіймає смугу по оба боки південної границі й 3) загірський, на південь від другого, що тягнеся аж до мадярської мовної територіі”' $[4,36]$. В останній, (третій) главі цієі публікації А. Княжинський окреслює межі Бойківщини та висловлює сподівання, що його стаття “дасть товчок до спеціяльних праць на тему говорів” $[4,36]$.

Намагаючить популяризувати серед збирачів фольклору науковий підхід до записування пісень, оповідань, пословиць, загадок тощо, в цьому ж першому “Літописі Бойківщини” за 1931 рік професор Княжинський поміщає статтю “Як записувати твори “усної словесности?” Він зазначає: “Мусимо - значить - даний твір записати так, щоби хтось другий, читаючи його, не тільки зрозумів його зміст, але й міг віддати всі звуки окремих слів так, як вони виглядали в устах їх рецитатора, від якого ми твір записали” $[10,155]$. Доктор Княжинський у статті пояснює в популярній формі основи транскрипції для запису творів “усної словесности”. На закінчення подає як приклад “Жіноцьку пісню” (колискову) з його рідного села Тисовиця, показавши три варіанти запису без збереження бойківського говору та із збереженням говору $[10,155]$.

У цій же книзі Княжинський є одним із авторів Miscellanea (альманаху), до якого подає "Причинки до звичаєвого права на Бойківщині. Свідоцтво землі. Кара за крадіж на полі”. У статті подає записаний ним давній звичай “свідоцтва землі”, коли відбувався спір за межу. Звичай полягав у закликанні у свідки землю. "Се свідоцтво мало більшу вагу від зізнань хочби найбільшої кількости противних свідків" $[6,164]$. Звичай виглядав, як перехід того, що взяв за свідка землю, з пластом землі га голові до того місця межі, яке собі визначив. Цей звичай А. Княжинський записав від 88-літнього Івана Матківського з села Маткова (повіт Турка), який запевнював, “що не раз обманці падали мертві посеред своєї дороги, не дійшовши до кінця межі. Коли ж хто здоровий дійшов до кінця межі, виграв спір, бо йому свідком була сама земля" $[6,164]$. 
В цій же статті А. Княжинський подає звичай кари за крадіж у полі, очевидцем якого у рідному селі Тисовиця (пов. Старий Самбір) був він сам у 1912 чи 1913 році. Звичай полягав у тому, що винних, які мусіли нести вкрадені снопи чи ін., водили селом, спиняючись біля кожної хати, господарі якої висловлювали своє обурення вчинком злодіїв. "Перейшовши ціле село мусіли ще вислухати довгої промови війта й тоді їм було вільно вернути в хату. Імовірно вже ніколи не забажали сердеги чужого дорібку. Те саме діється, коли хто вкрав інші землеплоди" $[6,165]$.

У грудні 1933 року в Самборі була закінчена праця А. Княжинського “3 бойківськолемківського пограниччя”, що була опублікована у 1934 році в третьому числі “Літопису Бойківщини”. У статті доктор Княжинський аналізує говірку села Стефкова Ліського повіту, що знаходиться, як він вважає, на пограниччі Бойківщини і Лемківщини. "Що торкається самої Стефкової, то виказує вона два виразні і доволі розділені мовні типи: старше покоління, головно жіноцтво, говорить ще виразно окресленим бойківським говором, - молоде покоління вносить в говірку села щораз більше лемківських признак, приймаючи головно сталий лемківський наголос, тверді приголосні, окремі слова і т. д." [3, 2]. У статті професор Княжинський подає детальний фонетичний аналіз говірки, “яка ще живе в устах кількох старших людей” $[3,2]$. На закінчення автор подає в скороченні обряд весілля в Стефковій, який був записаний ним “за Пазею Малецькою, жінкою літ 68, в часі свойого побуту в Стефковій влітку 1929 р." [3, 2].

У “Літописі Бойківщини” за 1938 рік, число 10, подана стаття А. Княжинського “Фонетика підгірського бойківського говору села Тисовиця (Турчанського повіту)", у якій автор займається “описом звукового запасу Тисовиці” $[9,113]$ на основі транскрипційної системи професора Яна Зілінського. Перед самим описом професор наголошує, що “подана нижче система звуків занотована мною у 20 рр. цього сторіччя й раніша; теперішній стан сильно змінений впливом літературної мови, головно серед молодого покоління" $[9,114]$.

Будучи викладачем у гімназіях та вчительській семінарії в Самборі, професор Княжинський, виховуючи молодь, залучав іiї до збирання фольклору. Ним неодноразово організовувались так звані “прогульки”, які були не лише відпочинкового характеру, а мали характер фольклорно-етнографічних експедицій.

Один 3 учнів А. Княжинського - Орест Горницький - у своїх спогадах "Про курну хату в с. Вовче”, пише: “Одного разі на паузі (перериві) скликав нас проф. Княжинський і заповів: “Хлопці зближаються свята "Wszystkich świętych" тож будемо мати два дні “вільного" отже поїдемо в гори... "на дівчата", - сказав 3 усмішкою, а по хвилині (коли побачив наші здивовані обличчя), додав: - поїдемо робити зарисовку і опис курних хат, які щороку щезають як миляні бульки". Серед учнів пригадую такі прізвища: Добрянський Калістрат зі Старого Самбора, Яремко Іван 3 Викіт, Гординський Адам, шляхтич з Гордині, Горницький Орест, цебто я. Було нас п’ятеро, але прізвища одного не пам'ятаю. Безперечно, серед нас, учнів, не було таких, які занимались би научною роботою в цілому того слова значенні (хоча один 3 нас Добрянський К. в будучому став професором фольклору та етнографії на Львівському університеті). Радше це була молодеча романтика, яка тягне нас в незнані мандри, а такі прогульки під керівництвом проф. Княжинського завсігди були веселі, цікаві і неповторні” $[1,2]$. Такі “прогульки” окрім запису традицій та зарисовок завершувалися зазвичай бесідою професора Княжинського зі своїми вихованцями: “Коли ми вже сиділи у вагоні, повертаючись до Самбора, професор Княжинський аналізував висліди нашої експедиції, зокрема "погляди" на курну хату старого газди: "Не треба осуджувати його погляди на курну хату, бо цей консерватизм, традиція і “зацофаність”, на перший погляд, являються непрогресивними, але вони допомогли зберегти і надбання народної культури, звичаїв, обрядів, народних пісень народного одягу і побуту" $[1,2]$.

Окрім того, Княжинський вважав, що повноцінне виховання українського патріота повинне базуватися на знанні свого краю. Тому старався, щоби вихованці гімназії відвідували музей “Бойківщина". Один з учнів професора на вечорі споминів, приуроченому до столітнього ювелею Антіна Княжинського, який відбувся 20 лютого 1993 року в Самборі, згадує: “Свого роду громадським, чи адміністративним заходом він добивається ... щоб зобов'язали учнів гімназії відвідувати ... наш славнозвісний музей. Якщо враховувати те, що уже тоді публікувалося у “Літописі Бойківщини”, якщо враховувати те, скільки людей було заангажовано у роботі по створенню музею, то безумовно, і кругозір розширювався, і знання поглиблювались, і патріотичні почуття відданості своєму народові там, безумовно, $є$ ".

3 втрачених творів Антіна Княжинського відомий рукопис, що вже була підготований до друку - "Українська духовність у зеркалі 
української народної пісні”. Робота над цією книгою відбувалася у 1939 році, в часі побуту А. Княжинського в Коломиї. “Коли совєцка окупація на якийсь час перервалася і наступив період конструктивного труду, я мав багато роботи, але мимо того, маючи в пам'яті матеріяли до другої праці (“Дух нації” - Д. В.), я насмілився написати замовлену роботу для видавництва Українського Центрального Комітету п. н. “Українська духовність в зеркалі української народної пісні”. В моїй концепції народна пісня особливо українська - була найважнішим обсерваційним матеріялом для тієї теми і з цього огляду я з великою приємністю взявся за цей труд тимбільше, що я заховав свою збірку народних пісень, не скриваючи ії від евентуальної ревізії. 3 другого боку робив я те для того, щоб заздалегідь приготовити частину матеріялу для другої праці. Цю працю передав я видавництву УЦК” [5, 4 - 5].

Теоретична частина підготованої до друку праці “Українська духовність в зеркалі української народної пісні” була втрачена у часі воєнних лихоліть: “...моя праця у видавництві УЦК пропала, пропалай їі копія. Щоб не дати їй загинути, попробую в недалекому майбутньому іiі реконструювати" $[5,5]$. В сучасному історикоетнографічному музеї "Бойківщина" збереглися лише чернетка збірки народних пісень, на основі яких А. Княжинський подав теоретичну частину, чернетка уривку зі статті “Дві верстви пісень” із першої частини книги і план праці.

Книга "Українська духовність в зеркалі української народної пісні” за планом професора Княжинського мала таку структуру: А теоретична частина; Б - Р. Купчинський: Ода до пісні; В - тексти пісень (у групах).

Теоретична частина містила шість розділів:

1. Незамічені вартості;

2. Пісня як матеріал соціологічних тез;

3. Заложення соціології;

4. Українські світоглядові вартості в проєкції народної пісні;

5. Синтез;

6. Вирівняність українського світогляду i значення цього явища.

Згідно плану А. Княжинського між теоретичною частиною та текстами пісень мала міститися поезія Р. Купчинського “Ода до пісні”, що написана 1919 року, слова якої якнайкраще відповідали задумові професора:

“... I матерню любов, і чар палкий кохання.

За свободою жаль і мрії про свободу,

І весь наш біль, всі наші сподівання.

Ти, дзеркало душі Країни та Народу!

Устами матері у пісню колискову
Вливаєш Ти любов до племени, до краю.

I донесе дитя Твою таємну мову,

I донесе вражіння незатерті

Аж до самої смерті..." $[13,78]$.

В заключній частині книги доктор Княжинський подає тексти пісень “у групах”. “Груп” упрофесора Княжинського налічується 29, до кожної із них він подає поетичну назву. Наприклад, збірки пісень зимового різдвяного циклу - колядки і щедрівки - мають назви "ІІ первовіку”, “Нова радість стала" i “Застилайте столи"; групи історичних та станових пісень подаються під назвами “Коли турки воювали”, “Слави добувати!”, “Ой не гаразд, Запорожці...”, “Ой ходив чумак...” та ін.; родинно-обрядові пісні подані в групах "Хочуть тебе люди взяти”, “На завжди”; родинно побутові - “Те, чого не минеш”, “Ой, люлі..." та ін.

Збережений фрагмент початкового розділу книги "Українська духовність в зеркалі української народної пісні” подаємо тут повністю: “Дві верстви пісень.

Уже $з$ побіжного, поверховного ногляду бачимо, що деякі групи пісень повторяються звичайно звязані з порою року, або з роковими святами, інші не держаться такого часового порядку і $\epsilon$, т. б. м. поза їх диктатом. Їх держить при житті щось інше, а саме їх зміст, їх тематика. На цей поділ не має впливу їх ритм, бо такі ж самі ритми виступають і в одній і в другій групі".

Збірка українських народних пісень доктора Антіна Княжинського містить матеріал з різних областей України - від західних її границь до східних. Більшість пісень, що мали увійти до книги “Українська духовність в зеркалі української народної пісні” записані самим Княжинським в часі його перебування в різних містах Західної України. Пісні ж, що належать до інших регіонів України включені до списку Княжинським, імовірно, на основі публікацій інших авторів, що були доступними у 30 -х роках: Філарета Колесси, Олени Пчілки, Андрія Конощенка, Миколи Лисенка та ін.

Професор Княжинський у поданих піснях зазначає лише місце походження пісні, але не вказує від кого і в якому році вони були записані. Винятком є цикл “Весільна пісня в дії” (1929 р.), інформацію про запис якого А. Княжинський подає у своїй праці “3 бойківсько-лемківського пограниччя".

Більшість бойківських та лемківських пісень записані професором Княжинським в час його життя та педагогічної роботи у Самборі.

Частина пісень збірки, що належать до гуцульських, професором Княжинським, імовірно, 
була зібрана починаючи з 1938 року, коли він був у Коломиї професором гімназії. Із зазначень під гуцульськими піснями чітко прослідковується один 3 маршрутів його “прогульок” горами: Косів Річка - Яворів - Жаб’є. Професор Княжинський про цей час згадує так: “. . . переді мною відкривіся розкішний, барвистий гуцульський світ. Я став студіювати соковитий гуцульський говір, що його в загальному знав уже раніше. На захід віл мене залишилась моя дорога Бойківщина, якій присвітив я три десятки років. Практичне знання душі народу виніс я з Бойківщини. Гуцульщина показала мені ті самі вартості, але в динамічній проєкції” $[2,6]$.

Перед початком другої світової війни А. Княжинський відходить від роботи у сфері соціології і зосереджує увагу на формуванні матеріалу до майбутньої книжки: “Я вирішив переждати цей рік, а тим часом вів дальше студії гуцульського говору, громадив матеріяли до праці на тему ваги народної пісні, як основного кута визначення духа нації. Так минула половина 1939 року" $[2,6]$.

Після приходу німців до Коломиї 2 липня 1941 року, професор Княжинський на доручення ОУН обійняв посаду голови Окрежного комітету. Всі його сили були спрямовані на організацію української влади у Коломиї. Окрім зустрічей 3 представниками німецької та мадярської армій, та структуруваня української влади в Коломиї, Антін Княжинський активно включився у справу розвитку української культури і освіти. Як і значна частина української передової інтелігенції, доктор Княжинський вірив у те, що німецька влада допоможе позбутися московського ярма. У промові на конференції 3 представниками німецької та мядярської армій прозвучали його слова: “будемо на наших землях будувати своє життя як самостійна Українська Держава вновому справедливому ладі, будемо розбудовувати i працювати разом 3 нашою Святою Церквою” [11].

13 липня 1941 року в Коломиї відбулося відкриття Окружного театру. "Зібране в театральному будинку україньке громадянство привітав голова Окружноїуправи п. Др. Княжинський, виголошуючи цінну промову, якою відкрив він діяльність окружного українського народного театру в Коломиї. В цій промові змалював він теперішні наші дні радомти і схвилювання. На наших очах, говорив п. Др. Княжинський, сповнюється мрія Шевченка, Франка, Лесі Українки та всього українського народу - встає Україна" [14].

Висновки. Життя i творчість Антіна
Петровича Княжинського- один з найяскравіших зразків служіння рідному народові.

Постать Антіна Княжинського є однією із видатних постатей в українській освіті, історії та науці. Його соціологічні, етнопсихологічні, мовознавчі та педагогічні праці належать до золотого фонду української та світової культури. Один з перших українських етнопсихологів, чиї грунтовні дослідження національної ментальності мають вагоме значення для розвитку сучасної України. Фольклористична діяльність А. Княжинського грунтується на розумінні ним значення вивчення усної словесності для збереження і розвитку української нації, для розвитку держави. Записані професором Княжинським звичаї та пісні і їх аналіз, фольклористичні та етнопсихологічні його праці мають велику вагу для розвитку сучасного мовознавства та фольклористики, історії національної культури.

\section{ЛІТЕРАТУРА}

1. Горницький О. Спомин минулих літ: Про курну зату в селі Вовче // Рукопис з родинного архіву Д. Василик, 1999. - 2 с.

2. Княжинський А. Дещо про себе // На дні СССР. - Нью Йорк: ООЧСУ, 1959. - с. 5-8.

3. Княжинський А. 3 бойківсько-лемківського пограниччя // Літопис Бойківщини. - Ч. 3. - Рік 1V. - Самбір: Т-во Бойківщина в Самборі, 1934. - C. 1-11.

4. Княжинський А. Межі Бойківщини // Літопис Бойківщини. - Ч.1. - Рік 1. - Самбір: Т-во Бойківщина в Самборі, 1931. - С. 24 - 37.

5. Княжинський А. Переднє слово //Дух нації: соціологічно-етнопсихологічна студія. - Нью Йорк - Філадельфія - Мюнхен: Наукове Товариство ім. Т. Шевченка в ЗДА, 1959. - С. 3 - 7.

6. Княжинський А. Причинки до звичаєвого права на Бойківщині. Свідоцтво землі. Кара за крадіж на полі / Miscellanea // Літопис Бойківщини. - Ч.1.- Рік 1. - Самбір: Т-во Бойківщина в Самборі, 1931. - С. 164 - 165.

7. Княжинський А. Творчий шлях Лесі Українки. Друге переглянене видання. Філадельфія, Союз Українок Америки, 1961. - 56 с.

8. Княжинський А. Філософія Шевченка: Шевченко - творець українського ідеалізму // Тарас Шевченко: Збірник доповідей світового конгресу української вільної науки для вшанування сторіччя смерти патрона НТШ. - Нью-Йорк Париж - Торонто: НТШ в ЗДА, 1962. - С. 27 - 39.

9. Княжинський А. Фонетика підгірського бойківського говору села Тисовиця (Турчанського повіту) //Літопис Бойківщини.-Ч. 10. - Рік VIII.-Самбір: Т-во Бойківщина в Самборі, 1938.-С. 113-117. 
10. Княжинський А. Як записувати твори “усної словесности” // Літопис Бойківщини. - Ч. 1. - Рік 1. - Самбір: Т-во Бойківщина в Самборі, 1931. C. $155-158$.

11. Конференція з представниками німецької і мадярської армій // Воля Покуття. - Ч. 2 - 3. Коломия, 12 липня 1941 р. - С. 1.

12. Куб'як Кость. Перший почесний громадянин Самбора. - Самбірські вісті від 20 лютого 1993 р. - C. 2.

13. Купчинський Р. Ода до пісні / Р. Купчинський // Тернопіль. - 1991. - С. 78.

14. Маніфестація Українців м. Коломиї // Воля Покугтя. - Ч. 4. - Коломия, 16 липня 1941 р. - С. 2.

15. Скорик М. В десятиліття існування Товариства та Музею "Бойківщина" в Самборі // Літопис Бойківщини. - Ч. 10. - Рік VIII. - Самбір: Т-во Бойківщина в Самборі, 1938. - С. 3 - 18.

\section{REFERENCES}

1. Hornytskyi, O. (1999). Spomyn mynulykh lit: Pro kurnu zatu v seli Vovche [The reminder of past years: About the dusty hut in the village of Vovche]. Manuscript from the family archive D. Vasylyk, $2 \mathrm{p}$. [in Ukrainian].

2. Kniazhynskyi, A. (1959). Deshcho pro sebe [Something about myself]. At the bottom of the USSR. New York: Organization for the Defense of Four Freedoms for Ukraine, pp. 5-8. [in Ukrainian].

3. Kniazhynskyi, A. (1934). Z boikivskolemkivskoho pohranychchia [From the Boyko-Lemkiv borderland]. Chronicle of Boykivshchyna. Number 3. Year IV. Sambir: Society Boykivshchyna in Sambir, 1934, pp. 1-11. [in Ukrainian].

4. Kniazhynskyi, A. (1931). Mezhi Boikivshchyny [Borders of the Boykivshchyna]. Chronicle of Boykivshchyna. Number 1. Year I. Sambir: Society Boykivshchyna in Sambir, pp. 24 - 37. [in Ukrainian].

5. Kniazhynskyi, A. (1959). Perednie slovo [The Foreword]. The Spirit of the Nation: SociologicalEthnopsychological Studio. New York - Philadelphia - Munich: The Scientific Society of them. T. Shevchenko in the State Duma, pp. $3-7$. [in Ukrainian].

6. Kniazhynskyi, A. (1931). Prychynky do zvychaievoho prava na Boikivshchyni. Svidotstvo zemli. Kara za kradizh na poli [Accusions to the customary law in the Boycott region. Land certificate. The punishment for stealing on the field]. Miscellanea. Chronicle of Boykivshchyna.
Number 1. Year I. Sambir: Society Boykivshchyna in Sambir, pp. 164-165. [in Ukrainian].

7. Knyazhinsky, A. (1961). Tvorchyi shliakh Lesi Ukrainky [Creative way of Lesya Ukrainka. Second revised edition]. Philadelphia, Women's Union of America, 56 p. [in Ukrainian].

8. Kniazhynskyi, A. (1962). Filosofiia Shevchenka: Shevchenko - tvorets ukrainskoho idealizmu. [Philosophy of Shevchenko: Shevchenko - the creator of Ukrainian idealism]. Taras Shevchenko: Collected papers at the world congress of free Ukrainian scholarship commemorating the centennial anniversary of the death of the death of Ukraine's poet Taras Shevchenko. New York Paris - Toronto, Shevchenko Scientific Society in the U. S. A. pp. 27 - 39. [in Ukrainian].

9. Kniazhynskyi,A. (1938). Fonetyka pidhirskoho boikivskoho hovoru sela Tysovytsia (Turchanskoho povitu) [Phonetics of the Podhorsky Boykiv dialect of village Tysovitsa (Turchansky district)]. Chronicle of Boykivshchyna. - Number 10. - Year VIII. Sambir: Society Boykivshchyna in Sambir, pp. 113 117. [in Ukrainian].

10. Kniazhynskyi, A. Yak zapysuvaty tvory "usnoi slovesnosty" [How to record works of "oral literature"]. Chronicle of Boykivshchyna. Number 1. Year I. Sambir: Society Boykivshchyna in Sambir, pp. 155 - 158. [in Ukrainian].

11. Konferentsiia z predstavnykamy nimetskoi i madiarskoi armii [Conference with representatives of the German and Magyar Army]. Voliya Pokuttia. Number 2-3. Kolomiya, July 12, 1941, p. 1. [in Ukrainian].

12. Kubiak Kost. Pershyi pochesnyi hromadianyn Sambora [The first honorary citizen of Sambor]. Sambir news from February 20, 1993, p. 2. [in Ukrainian].

13. Kupchynskyi, R. (1991). Oda do pisni [Oda to the song]. Ternopil, p. 78. [in Ukrainian].

14. Manifestatsiia Ukraintsiv m. Kolomyi [Manifestation of the Ukrainians of Kolomyia]. Volya Pokuttia. Number 4. Kolomiya, July 16, 1941, p. 2. [in Ukrainian].

15. Skoryk, M. V desiatylittia isnuvannia Tovarystva ta Muzeiu "Boikivshchyna" v Sambori [In the decade of the Society and the Museum "Boykivshchyna" in Sambir]. Chronicle of Boykivshchyna. Number 10. Year VIII. Sambir: Society Boykivshchyna in Sambir, pp. 3-18. [in Ukrainian].

Стаття надійшла до редакції 05.09.2018

\section{G58080

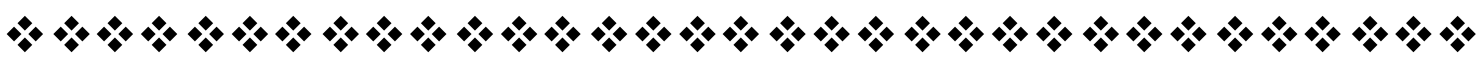

